\title{
The Characteristics of Alumina Particle Reinforced Pure Al Matrix Composite
}

\author{
N. PARVIN ${ }^{a}$ AND M. RAHIMIAN ${ }^{b}$ \\ ${ }^{a}$ Faculty of Mining and Materials Engineering, Amirkabir University of Technology (AUT) \\ Hafez Ave., Tehran, Iran \\ ${ }^{b}$ Faculty of Engineering, Islamic Azad University — Semnan Branch, Damghan Rd. km 5, Semnan, Iran \\ $\mathrm{Al}_{2} \mathrm{O}_{3}$ is widely used as the reinforcing additive in the metal matrix composites. The influence of $\mathrm{Al}_{2} \mathrm{O}_{3}$ \\ particle size on the density, hardness, microstructure, yield stress, compression strength, and elongation of the \\ sintered $\mathrm{Al}-\mathrm{Al}_{2} \mathrm{O}_{3}$ composites were investigated. In the present study, $10 \mathrm{wt} \%$ of $\mathrm{Al}_{2} \mathrm{O}_{3}$ powder with three different \\ particle sizes $(3,12$ and $48 \mu \mathrm{m})$ were used in the production of the samples. Powder metallurgy technique was \\ utilized to obtain more homogeneous $\mathrm{Al}_{2} \mathrm{O}_{3}$ distribution across the composites. The samples were cold pressed \\ at $440 \mathrm{MPa}$, and sintered at $550{ }^{\circ} \mathrm{C}$ for $45 \mathrm{~min}$. Results showed that the relative density of the composite was \\ initially increased with decreasing particle size. However, it was decreased with further particle size reduction. It \\ was also pointed out that the mechanical properties of the specimens were increased with decreasing particle size. \\ The grain size and particle distribution homogeneity was decreased with raising the particle size.
}

PACS: $81.05 . \mathrm{Ni}$

\section{Introduction}

Some of the material demands in the advanced industries cannot be fulfilled by monolithic materials.

Therefore, composite materials have been developed. The combination of desired properties of metals (ductility and toughness) and ceramics (high strength and high modulus) is the aim of composites production. Composite materials, especially metal matrix composites (MMCs), have found various applications in the new industries [1].

Due to the desired properties of aluminum matrix composites, such as low weight, high specific strength and excellent wear resistance, they have received a great interest in the recent years. Compared to the ferrous alloys, aluminum alloys have lower density and higher strength to weight ratio, higher thermal and electrical conductivity. On the other hand, they are cheaper than the lighter metals, such as $\mathrm{Mg}$ and $\mathrm{Ti}$ [1].

Among the ceramic reinforced materials, $\mathrm{SiC}$ is the most common used in MMCs. The second most used reinforcement is $\mathrm{Al}_{2} \mathrm{O}_{3}$. Compared with $\mathrm{SiC}$ it is more stable and inert and has better corrosion and high temperature resistance. The influence of these reinforcements to aluminum alloys has been the subject of a significant amount of research work $[2,3]$.

\section{Experimental procedures}

The starting materials used in the current investigation were $\mathrm{Al}$ and $\mathrm{Al}_{2} \mathrm{O}_{3}$ powders. The purity and average size of $\mathrm{Al}$ powder was $97.7 \%$ and $30 \mu \mathrm{m}$, respectively. $10 \mathrm{wt} \%$ of $\mathrm{Al}_{2} \mathrm{O}_{3}$ powder with three different sizes of 3 ,
12 and $48 \mu \mathrm{m}$ were added as the reinforcing material. The chemical composition of $\mathrm{Al}_{2} \mathrm{O}_{3}$ powder is shown in Table I.

TABLE I

The chemical composition of $\mathrm{Al}_{2} \mathrm{O}_{3}$ powder.

\begin{tabular}{c|c|c|c|c}
\hline \hline $\begin{array}{c}\text { Others } \\
{[\mathrm{wt} \%]}\end{array}$ & $\begin{array}{c}\mathrm{CaO} \\
{[\mathrm{wt} \%]}\end{array}$ & $\begin{array}{c}\mathrm{TiO}_{2} \\
{[\mathrm{wt} \%]}\end{array}$ & $\begin{array}{c}\mathrm{Fe}_{2} \mathrm{O}_{3} \\
{[\mathrm{wt} \%]}\end{array}$ & $\begin{array}{c}\text { Alumina } \alpha \\
{[\mathrm{wt} \%]}\end{array}$ \\
\hline 0.3 & 1.2 & 1.7 & 0.7 & 96.1
\end{tabular}

Figure 1 shows the scanning electron microscopy (SEM) micrograph of the $\mathrm{Al}$ and $\mathrm{Al}_{2} \mathrm{O}_{3}$ powders. Pre-weighed amounts of aluminum $(\mathrm{Al})$ and aluminum oxide $\left(\mathrm{Al}_{2} \mathrm{O}_{3}\right)$ powders were mixed in high energy rotary ball mill (Fritsch - Pulverisette-5). The powders were ball milled in ethanol alcohol for 60 min using WC-Co container and balls. The mixtures were then dried in a vacuum evaporator and cold pressed under $440 \mathrm{MPa}$ into samples having dimensions of $d=16 \mathrm{~mm}, h=16 \mathrm{~mm}$ using a hardened tool steel die and a hydraulic press. The interior of the die was coated with a die lubricant consisting of a saturated solution of stearic acid in acetone. The green samples were then sintered for $45 \mathrm{~min}$ at $550^{\circ} \mathrm{C}$, using a heating rate of $20^{\circ} \mathrm{C} / \mathrm{min}$, under argon atmosphere in an electric furnace. The furnace was shut down and allowed samples to cool to room temperature.

For microstructural evaluations, dense sintered specimens were surface ground and polished with alumina down to $3 \mu \mathrm{m}$ surface finish. The polished surfaces were then etched with Keller's agent. The microstructures were observed by a scanning electron microscope (Philips, XL30 and Tescan, VEGA-II xmu). The density of the 


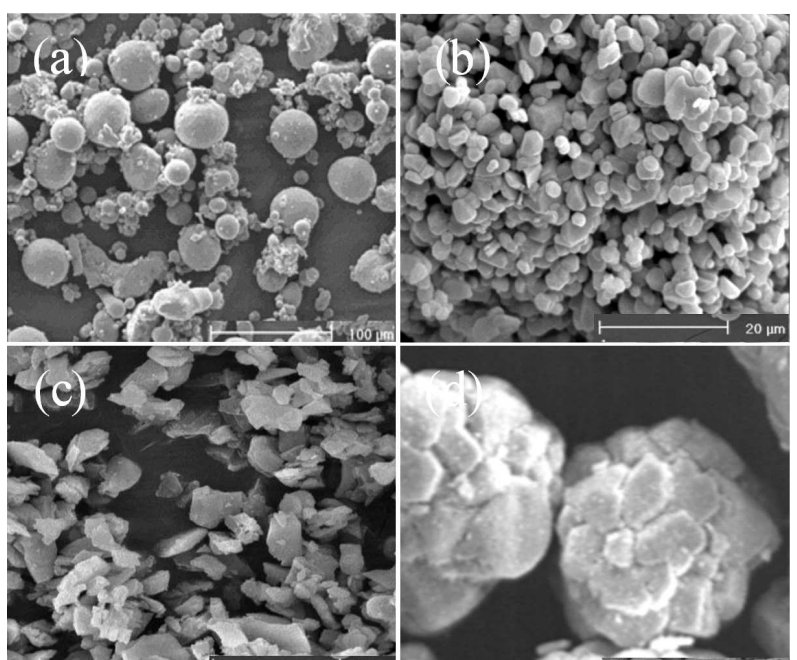

Fig. 1. SEM micrographs of $\mathrm{Al}$ and $\mathrm{Al}_{2} \mathrm{O}_{3}$ powders: (a) $\mathrm{Al}$, (b) $\mathrm{Al}_{2} \mathrm{O}_{3}-3 \mu \mathrm{m}$, (c) $\mathrm{Al}_{2} \mathrm{O}_{3}-12 \mu \mathrm{m}$, (d) $\mathrm{Al}_{2} \mathrm{O}_{3}-48 \mu \mathrm{m}$.

samples was measured by the Archimedes method using densitometer (Sartorius-LA2305). The hardness of the sintered composites was determined with the Brinell standard method, using a load of $30 \mathrm{kgf}$ and indenter diameter of $2.5 \mathrm{~mm}$ (Eseway-Avery Denison Co.). The reported values represent the average of 3 measured values. The compression strength of samples was measured according to the ASTM E9 standard. The loading rate was $0.5 \mathrm{~mm} / \mathrm{min}$ in all experiments [4].

\section{Results and discussions}

The effect of $\mathrm{Al}_{2} \mathrm{O}_{3}$ particle size on the relative density of the composites is depicted in Table II. The presented data reveal that the relative density of the composites increased with increasing the particle size of $\mathrm{Al}_{2} \mathrm{O}_{3}$ powder up to $12 \mu \mathrm{m}$. However, particle size of $48 \mu \mathrm{m}$ led to relative density reduction. Relatively the same size of $\mathrm{Al}(30 \mu \mathrm{m})$ and $\mathrm{Al}_{2} \mathrm{O}_{3}(48 \mu \mathrm{m})$ reduced the powder mixture compactability during the pressing of the samples. The small $\mathrm{Al}_{2} \mathrm{O}_{3}$ particles $(12 \mu \mathrm{m})$ can be located in the voids formed between the $\mathrm{Al}$ particles. However, the size of big $\mathrm{Al}_{2} \mathrm{O}_{3}$ particles $(48 \mu \mathrm{m})$ is much larger than the voids size, therefore they are not well fitted with the voids. Accordingly, the large $\mathrm{Al}_{2} \mathrm{O}_{3}$ particles $(48 \mu \mathrm{m})$ prevent appropriate compaction of the green samples, which reduces the relative density of the specimens. Furthermore, the sinterability of the powders decreases with high particle size. This can be considered as a further cause of porosity in composites containing large $\mathrm{Al}_{2} \mathrm{O}_{3}$ particles $(48 \mu \mathrm{m})$. The data also show that the pure $\mathrm{Al}$ has the maximum relative density.

Figure 2 illustrates the effect of $\mathrm{Al}_{2} \mathrm{O}_{3}$ particle size on the microstructures of the composites under investigation. As SEM micrographs show, the grain size of the samples increased with specimens having large reinforce-
TABLE II

The effect of $\mathrm{Al}_{2} \mathrm{O}_{3}$ particle size on the relative density of the composites.

\begin{tabular}{c|c|c|c}
\hline \hline $\begin{array}{c}\mathrm{Al}_{2} \mathrm{O}_{3} \text { size } \\
{[\mu \mathrm{m}]}\end{array}$ & $\begin{array}{c}\text { Theoretical } \\
\text { density } \\
{\left[\mathrm{g} / \mathrm{cm}^{3}\right]}\end{array}$ & $\begin{array}{c}\text { Sintered } \\
\text { density } \\
{\left[\mathrm{g} / \mathrm{cm}^{3}\right]}\end{array}$ & $\begin{array}{c}\text { Relative } \\
\text { density } \\
{[\%]}\end{array}$ \\
\hline pure aluminum & 2.7 & 2.68 & 99.23 \\
3 & 2.78 & 2.71 & 97.41 \\
12 & 2.78 & 2.73 & 98.2 \\
48 & 2.78 & 2.72 & 97.84
\end{tabular}

ments, since, at a constant amount of reinforcement, distance between the particles increased with large particle size according to Eq. (1) [5]:

$$
\lambda=4(1-f) r / 3 f
$$

where $\lambda$ is the distance between the reinforcement particles, $f$ is the particles volume fraction, and $r$ is the particle radius, assuming them as spherical.

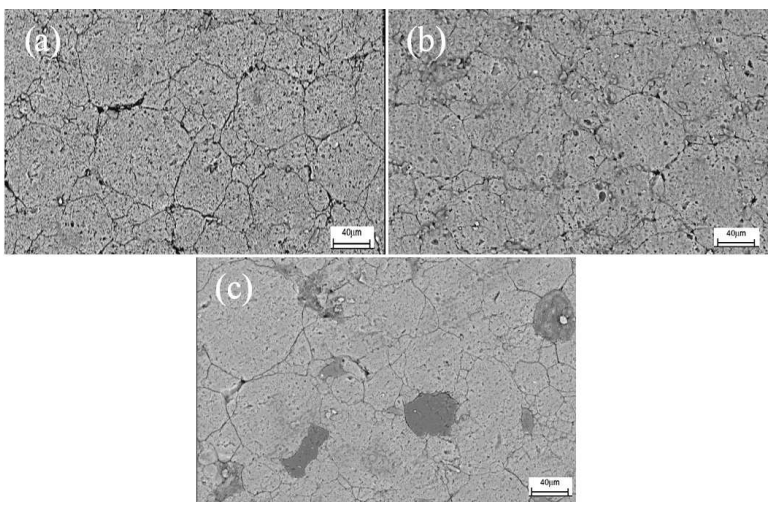

Fig. 2. The effect of $\mathrm{Al}_{2} \mathrm{O}_{3}$ particle size on the microstructure of the composites: (a) $3 \mu \mathrm{m}$, (b) $12 \mu \mathrm{m}$, (c) $48 \mu \mathrm{m}$.

Therefore, reduced obstacles against grain boundary movement were present, leading to faster and easier grain boundaries movement.

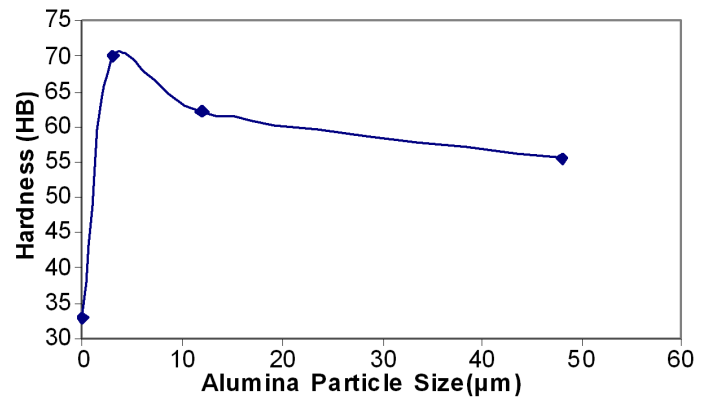

Fig. 3. The effect of $\mathrm{Al}_{2} \mathrm{O}_{3}$ particle size on the hardness of the composites.

The effect of the additive grain size on hardness is shown in Fig. 3. It demonstrates that the hardness 
of $\mathrm{Al}-\mathrm{Al}_{2} \mathrm{O}_{3}$ composites is higher than that of the aluminum alloy which is caused by extremely high hardness of $\mathrm{Al}_{2} \mathrm{O}_{3}$, compared to the hardness of pure $\mathrm{Al}$.

The higher hardness of the composites can also be attributed to the fact that $\mathrm{Al}_{2} \mathrm{O}_{3}$ particles prevent the movement of dislocations. The number of these obstacles increased with the particle size reduction, therefore the overall hardness of the composites increased. Moreover, the amount of defect within the grains increased with large grain size. Therefore, the hardness of specimens having large particles was lower than that of the small ones [6-9].

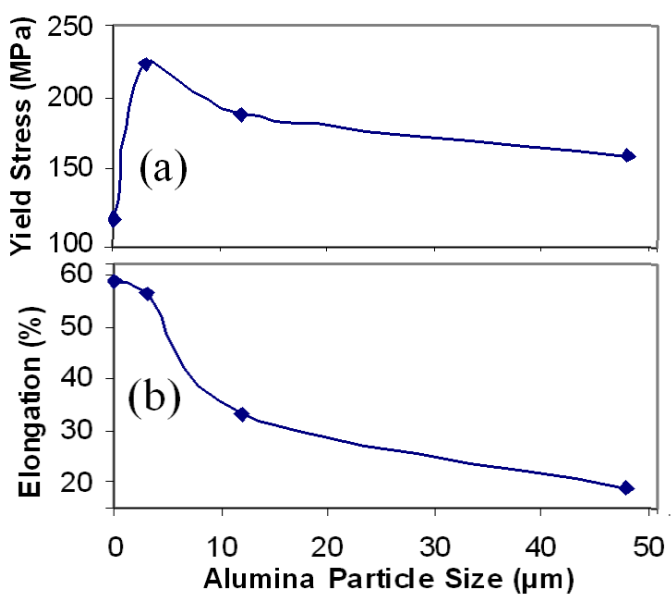

Fig. 4. (a) Variation of the yield strength of the composites as a function of $\mathrm{Al}_{2} \mathrm{O}_{3}$ particle size, (b) variation of the elongation to fracture of the composites as a function of $\mathrm{Al}_{2} \mathrm{O}_{3}$ particle size.

Figure $4 \mathrm{a}$ and $\mathrm{b}$ presents the effect of $\mathrm{Al}_{2} \mathrm{O}_{3}$ particle size on the strength of samples. The data reveal that yield stress and compression strength increased with $\mathrm{Al}_{2} \mathrm{O}_{3}$ reinforcement addition. This is due to the hobble effect which describes the role of $\mathrm{Al}_{2} \mathrm{O}_{3}$ particles against dislocation movement. Moreover, different thermal expansion coefficients of $\mathrm{Al}_{2} \mathrm{O}_{3}$ and $\mathrm{Al}$ create stress which may increase dislocation density and then composite strength.

The figures also show that yield stress and compression strength increased with low particle size [10]. According to Eq. (1), at a constant amount of reinforcement, the number of the particles increases with fine particle size. Therefore, the level of dislocation strengthening was more in the case of finer particle reinforcement.

Elongation behavior of the composites as a function of reinforcement particle size is shown in Fig. 4b.

It can be observed that the amount of elongation to fracture increased with particle size increase, which is directly proportional to the amount of porosity [11]. It can also be seen that the elongation of the unreinforced $\mathrm{Al}$ is higher than of the reinforced Al. According to the mixture rule the elongation of $\mathrm{Al}$ decreases with $\mathrm{Al}_{2} \mathrm{O}_{3}$ addition, since the elongation properties of $\mathrm{Al}_{2} \mathrm{O}_{3}$ is much lower than that of the $\mathrm{Al}$.

\section{Conclusions}

1. The relative density of the composites increased with increasing $\mathrm{Al}_{2} \mathrm{O}_{3}$ particle size up to $12 \mu \mathrm{m}$. However, raising the particle size to $48 \mu \mathrm{m}$ led to abrupt reduction in relative density. The relative density of unreinforced $\mathrm{Al}$ was higher than that of the $\mathrm{Al}-\mathrm{Al}_{2} \mathrm{O}_{3}$ composite.

2. The grain size of the samples was higher with increasing reinforcement particle size.

3. The hardness of the $\mathrm{Al}-\mathrm{Al}_{2} \mathrm{O}_{3}$ composites was higher than that of the aluminum alloy. The hardness of the $\mathrm{Al}-\mathrm{Al}_{2} \mathrm{O}_{3}$ composites increased in the presence of fine $\mathrm{Al}_{2} \mathrm{O}_{3}$ particles.

4. Yield stress and compression strength increased with the amount of $\mathrm{Al}_{2} \mathrm{O}_{3}$ reinforcement addition. Similar trend was observed when fine particle size of reinforcement was employed.

5. The elongation to fracture of unreinforced $\mathrm{Al}$ was higher than that of the $\mathrm{Al}-\mathrm{Al}_{2} \mathrm{O}_{3}$ composites. Also the amount of elongation to fracture increased by rising the particle size.

\section{References}

[1] M. Kok, J. Mater. Process. Technol. 161, 381 (2005).

[2] M. Rahimian, N. Parvin, N. Ehsani, Mater. Design 32, 1031 (2011).

[3] M. Kok, K. Ozdin, J. Mater. Process. Technol. 183, 301 (2007).

[4] B. Torres, H. Lieblich, J. Ibanez, A. Garcia-Escorial, Scr. Mater. 47, 45 (2002).

[5] G.E. Dieter, Mechanical Metallurgy, 3rd ed., McGraw-Hill, New York 1976.

[6] A. Slipenyuk, V. Kuprin, Yu. Milman, V. Goncharuk, J. Eckert, Acta Mater. 54, 157 (2006).

[7] H. Sevik, S.C. Kurnaz, Mater. Design 27, 676 (2006).

[8] L.A. Dobrzanski, A. Wlodarczyk, M. Adamiak, J. Mater. Process. Technol. 162-163, 27 (2005).

[9] M. Sameezadeh, M. Emamy, H. Farhangi, Mater. Design 32, 2157 (2011).

[10] A. Slipenyuk, V. Kuprin, Yu. Milman, V. Goncharuk, J. Eckert, Acta Mater. 54, 157 (2006).

[11] R.M. German, Powder Metallurgy Science, Metal Powder Industries Federation, Princeton 1984. 